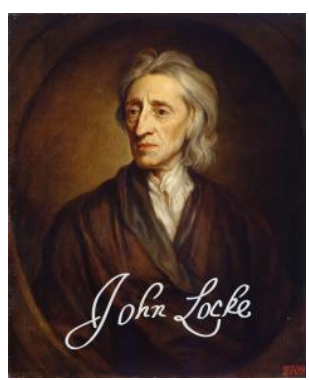

LOCKE STUDIES

Vol. 17

https://doi.org/10.5206/ls.2017.879 | ISSN: 2561-925X

Originally published: 2017

Published online: 01 JANUARY 2019

(C) Locke Studies, 2017

\title{
Shaftesbury, Locke, and their Revolutionary Letter?
}

\author{
D.N. DELUNA (UNIVERSITY COLLEGE, LONDON)
}

A corrigendum for this article was published in vol. 18 of Locke Studies available here. Scholars are kindly asked to reference the corrigendum only and not this version of the article.

For more information about this article:

see this article's webpage.

Locke Studies is published by The John Locke Society.

This is an open access article published under the terms of the Creative Commons AttributionNonCommercial-ShareAlike 4.0 International license, which permits use, distribution and reproduction in any medium, provided the original work is properly cited and shared under the original license. 


\title{
SHAFTESBURY, LOCKE, AND THEIR REVOLUTIONARY LETTER?
}

\author{
D. N. DELUNA
}

I knew of none besides the Duke [of Monmouth] who had an interest in the minds \& affections of the people to draw them to Arms for asserting their Rights \& Liberties

Robert Ferguson (1683)

\section{$\S 1$}

Late in 1675, the anonymous Letter from a Person of Quality, to His Friend in the Country was condemned in the House of Lords as a 'dangerous Book', indeed a 'lying, scandalous, and seditious Book'. The Peers ordered it to be burned by the public hangman, and opened an investigation designed to discover its author, printer, and publisher. ${ }^{2}$ About this search and its success in tracking the author(s) down, very little is known. But as J. R. Milton and Philip Milton, who included the pamphlet in their Clarendon edition of John Locke's Essay Concerning Toleration and his Other Writings on Law and Politics, 1667-1683, have pointed out, "no one has ever doubted that it was written by someone in Shaftesbury's circle and for Shaftesbury's purposes. ${ }^{3}$

1 Robert Ferguson, 'Concerning the Rye House business', printed in James Ferguson, Robert Ferguson, the Plotter; or, The Secret of the Rye-House Conspiracy and the Story of a Strange Career (Edinburgh, 1887), 420.

${ }^{2}$ See Journal of the House of Lords [henceforth $L J$ ], 13:12, 14.

${ }^{3}$ J. R. Milton and Philip Milton, eds., John Locke: An Essay Concerning Toleration and Other Writings on Law and Politics, 1667-1683 (Oxford, 2006), 75. See also 9497 for a detailed account of what is known of the various attempts to discover the Letter's true origins. One was initiated by the Lords, while another was conducted by Secretary of State Joseph Williamson; and there were subsequent investigations by other official parties. 
John Locke, Shaftesbury's secretary at the time, has long been a suspected collaborator in its production. ${ }^{4}$

Just over a decade ago, Philip Milton revisited the picture of Locke as a Whig conspirator in the pages of this journal. On the twentieth anniversary of the publication of Richard Ashcraft's Revolutionary Politics and Locke's 'Two Treatises of Government' (1986), he presented a case for seeing Locke in an aloof posture from the treasonous activities of Anthony Ashley Cooper, $1^{\text {st }}$ Earl of Shaftesbury. ${ }^{5}$ This essay is primarily concerned with early revolutionary agitation under Shaftesbury's auspices. It will deal with authorial practice within the Shaftesbury circle in 1675 , specifically the practice of concealing incendiary messages in its propaganda. It will call attention to certain highly seditious passages in the Letter from a Person of Quality. These have so far gone unnoted. Two of them had already appeared in another work issuing out of the circle. This was the Reasons against the Bill for the Test, scribally published in the spring of 1675.

What follows here is, first, a slightly new account of the parliamentary context of these publications. I shall then offer some interpretive keys to the covert passages in the Reasons and Letter. Certain issues raised by these, including the question of the timing of Shaftesbury's sponsorship of anti-government insurgency and Locke's authorship of the seditious passages, will be considered in two subsequent sections.

\section{$\$ 2$}

Both the Reasons and Letter had as their occasion the furore raised in Parliament over the proposed Test Bill of 1675, of

4 For a survey of scholarly thought and opinion concerning Locke's possible collaboration on the Letter from a Person of Quality, see Milton and Milton, Essay Concerning Toleration, 101-12.

5 Philip Milton, 'Locke the Plotter: Ashcraft's Revolutionary Politics Reconsidered', Locke Studies 7 (2007): 53-112. See also Philip Milton, 'John Locke and the Rye House Plot', Historical Journal 43 (2000): 647-68, in which Shaftesbury's confederates distance themselves from their leader in confessions which depict him as a loose cannon who had become a mere shadow of his once spry-minded self. 
which Shaftesbury was a leading opponent. ${ }^{6}$ Entitled 'An Act to prevent the Dangers which may arise from Persons disaffected to the Government', it required all officeholders and parliamentarians to disavow taking arms against kings, and to foreswear all attempts to change the government of Church and State. ${ }^{7}$ Not only could the terms of the Bill be read as threatening to members of the Houses who were Presbyterians. They could fan Anglican fears of these colleagues. For they were a reminder of the role of anti-prelatical groups in the Great Rebellion of 1642, whose theories of political resistance had divided them from Churchmen. Inevitably, members who were Anglicans would have registered that their fellow Presbyterians could not in good conscience pass the proposed Test, and for reasons that were disturbing. As for themselves, they could do so without qualms.

Back in 1674, Charles II had begun preparing the ground for the parliamentary session in which the Bill was launched. At this juncture, he was pursuing a policy of Anglican appeasement, to induce Parliament to loosen the purse strings. In October, he had his Lord Treasurer, Thomas Osborne, $1^{\text {st }}$ Earl of Danby, meet with Bishop George Morley in order to arrange for future conferences between his ministers and bishops. These took place around the turn of the year, at Lambeth and other venues. Their purpose was to concert measures for safeguarding the Church from the dangers of popery, thereby hoping to allay fears of such 'against the next session of Parliament' ${ }^{8}$ Another, though less explicit, objective was to crack down on Protestant schismatics.

${ }^{6}$ Detailed accounts of the background and purpose of this Bill include those by Andrew Browning, Thomas Osborne: Earl of Danby and Duke of Leeds, 1632-1712 (3 vols., Glasgow, 1944-51), I, 146-64; K. H. D. Haley, The First Earl of Shaftesbury (Oxford, 1968), ch. 18; Mark Goldie, 'Danby, the Bishops and the Whigs', in The Politics of Religion in Restoration England, ed. Tim Harris, Paul Seaward, and Mark Goldie (Oxford, 1990), 75-83; Milton and Milton, Locke: Essay Concerning Toleration, 75-89.

7 A copy of this Test Bill is conveniently printed in Milton and Milton, Locke: Essay Concerning Toleration, 417-19.

${ }^{8}$ Carte MS 72, fo. 229, Robert Southwell to James Butler, $1^{\text {st }}$ Duke of Ormonde, 24 October 1674; quoted in Browning, Thomas Osborne, 1:147. 
The timing of the start of this scheme may have been linked to news of the pregnancy of Mary Beatrice of Modena-the Catholic wife of Charles's brother, James, Duke of York. Should she give birth to a son, he might survive to become second in line to inherit the throne, after his Catholic father. James had married Mary in 1673, having resigned from his post of Lord High Admiral rather than subscribe to the first Test Act, which had passed into law earlier that year. In January 1675, Mary gave birth to a baby girl, Catherine Laura, who, unlike any male heir, stood behind James's two Protestant daughters (by his prior marriage to Anne Hyde) in the line of succession. But the threat that Mary would give birth to a male heir soon re-emerged. She was newly pregnant in March. ${ }^{9}$ Parliament met on 13 April.

Charles, in his speech on Opening Day, spoke of his financial needs, if only briefly. At greater length he expressed a desire to deliver securities to the Church, (despite his own Catholic sympathies and possible Catholic leanings). Thus, he was readying the way for the introduction of the Test Bill. His own interest in the measure was strategic, aimed at minimizing the religious concessions he was prepared to make in return for financial supply in the future. The Test catered to orthodox Anglicans alone. There was certainly nothing in it for nonconformists, Catholic or Protestant. Charles was not offering them indulgence, as he had in $1672 .{ }^{10}$ With this Bill as a deliberative centrepiece, he was effectively foreclosing on productive input from Anglicans and Presbyterians combined. Such a united force could be expected to be too vehemently antipapist and offensive to the royal prerogative. For instance, it might insist on a provision excluding Catholics from the

${ }^{9}$ Commentators, in discussing the lead-up to this Test Bill, have so far not emphasized this context.

${ }^{10}$ Shaftesbury's strong support for the Declaration of Indulgence of that year, and the attempt to give it statutory force can be followed in The History of Parliament: The House of Lords, 1660-1715, ed. Ruth Paley, 5 vols. (Cambridge, 2016), under Anthony Ashley Cooper, s.v. (by Paul Seaward), 2:690-91, 692; henceforth HoP: Lords, 16601715 . 
succession. $^{11}$

The king's motives in presenting the Bill were not identical to those of his ministers, Danby and Lord Keeper Heneage Finch (later Lord Chancellor and first earl of Nottingham). ${ }^{12}$ These hard-line Anglicans wished to maximize royal concessions to the Church. It was at Danby's house that the measure was framed. Unlike Charles, he and Finch hoped that the Bill would deal a blow to popery and religious dissent. The gamut of Danby's objectives was neatly summed up by his brother-in-law Robert Bertie, $3^{\text {rd }}$ Earl of Lindsey: 'The aim you have is to settle the Church and State; to defend the one against schismatics and papists, and the other against Commonwealths men and rebels'. ${ }^{13}$ Naturally, Danby also believed that Parliament could best be managed on the Crown's behalf when an Anglican and Cavalier party was dominant there. ${ }^{14}$ Here, too, was a rationale in which his own career interest in parliamentary management was invested. ${ }^{15}$

The Bill was put forward in the Lords on 15 April. Its chief

${ }^{11}$ In the parliamentary session of 1673 , Charles may have recognized the benefits to be gained from a policy of Anglican appeasement, after his bid for supply had been jeopardized by his late Declaration of Indulgence. He responded by withdrawing the Declaration, welcoming in its stead legislation 'to secure the Peace of the Church and Kingdom'; see Journal of the House of Commons [henceforth CJ], 9:256. The session saw the passage of An Act for preventing Dangers which may happen from Popish Recusants, after An Act for raising the Sum of Twelve Hundred Thirty-eight Thousand Seven Hundred and Fifty Pounds, for Supply of His Majesty's extraordinary Occasions had received the royal assent; see $L J, 12: 584$.

${ }^{12}$ For a fuller account of Danby's motives, consult Milton and Milton, Locke: Essay Concerning Toleration, 82-83. Commentators on the Bill to this point have not sufficiently noted how distinct these two interests were.

${ }^{13} H M C$, Lindsey MS, 377, Lindsey to Danby, 25 Aug. 1675.

${ }^{14}$ But, as Milton and Milton note, there was a flipside to this stance: 'A solidly Anglican and Cavalier Parliament would indeed support the King, but (as James II was to find in 1685) only if he pursued policies it favoured' (Locke: Essay Concerning Toleration, 83).

${ }^{15}$ On this, consult the account of Danby's motives given by Robert Boyle, $1^{\text {st }}$ Earl of Orrery, quoted in Milton and Milton, Locke: Essay Concerning Toleration, 82-83. 
handlers were Danby and Finch. ${ }^{16}$ James, Duke of York, also spoke up for it. Charles added pressure by regularly attending the deliberations. Debate was heated, and it went on for weeks. Predictably enough, those outside the citadels of high Anglicanism were alarmed. Shaftesbury, in particular, evidently poured his heart and soul into trying to defeat the measure. Its other opponents included George Villiers, $2^{\text {nd }}$ Duke of Buckingham, Denzil Lord Holles, Philip Lord Wharton, and George Savile (later $1^{\text {st }}$ Marquess of Halifax). ${ }^{17}$ On 9 June, the measure was wrecked, possibly by obstructionist tactical manoeuvering that led Charles to prorogue the session that day. ${ }^{18}$ Meanwhile, out of doors there had appeared two scribally published tracts on the parliamentary debate. It seems clear enough that both came from the Shaftesbury circle. These were the Reasons against the Bill for the Test and The Earle of Shaftesbury's Speech in the H. of L. against the Test. Portions of these works would furnish a substantial amount of material for the Letter from a Person of Quality, as would another scribal

${ }^{16}$ Lindsey introduced the Bill in the Lords. Danby may have chosen him for this purpose in order to mitigate anticipated hostilities from opponents of the measure, since Lindsey's wife was the daughter of the ex-Cromwellian Philip Lord Wharton.

${ }^{17}$ A more inclusive list of the Bill's opponents can be had by consulting the rosters of those of who signed protests against resolutions in its favour; see these signatories in $L J, 12: 665,669,674,677$; cf. the lists of protesters as given in the Letter from a Person of Quality, in Milton and Milton, Locke: Essay Concerning Toleration, 159-61, 22123, 350, 351, 352, 354; but on William Lord Paget, see 220 and 354 (n. 2). Consult also what may have been canvassing lists of likely opponents, as well as proponents, in BL Add. MS 28091, fos. 161, 175, 177.

${ }^{18}$ Interference was run by the bicameral conflict that broke out over the legal case Shirley v. Fagg. It absorbed the attention of members of both Houses because, together with another dispute in Crispe v. Dalmahoy, it touched on their respective privileges and immunities, and the question of jurisdictional rights and procedures. For an overview of the controversy of Shirley v. Fagg, and its possible contrivance as a means of obstructing the progress of the Test Bill, see Andrew Swatland, The House of Lords in the Reign of Charles II (Cambridge, 1996), 134-36. Shaftesbury may well have been responsible for whipping up this diversion from current parliamentary business. However, one contemporary, Gilbert Burnet, believed that it was an accident, and that Shaftesbury falsely claimed credit for it; see Burnet's account in BL Add MS 63057B, f. $31^{\text {r }}$. 
publication, Shaftesbury's Speech of 20 October. ${ }^{19}$ Parliament next met in October, in a session that lasted until 22 November. The Bill was not revived then, or anytime thereafter. The Letter probably appeared sometime after the circulation of Shaftesbury's Speech. It was first condemned in the Lords on 8 November. ${ }^{20}$

\section{$\$ 3$}

To date, it has been thought that Shaftesbury's political opposition in 1675 did not go beyond what has been known of his efforts to defeat the Test Bill and to secure the dissolution of the Long Parliament and the election of a new Parliament. But urgently topical allegory concealed in the Reasons and Letternever before remarked upon by modern scholars-already agitated for armed insurgency against a government presented as prey to popish and foreign captors. It urged a violent answer to the danger of Catholic and French rule, at a time when its legislative solutions from Presbyterians had been choked off. These passages objected to the clause in the proposed Bill which required the takers of the Test to 'abhor that Traiterous Position of taking Arms by his Authority against his Person, or against those that are Commissioned by him in pursuance of such Commissions'. ${ }^{21}$

Against this, the Reasoner argued that on one memorable occasion in the English past it had been positively conscientious so to appear in arms. That was during the Wars of the Roses, in a case 'known to you all (and what hath been may very well be supposed to be hereafter)':

I mean that famous instance of Henry the $6^{\text {th }}$ who being a soft and weak

${ }^{19}$ The histories and bibliographical descriptions of texts are available in Milton and Milton, Locke: Essay Concerning Toleration, 89-97, 195-233.

${ }^{20}$ On this day, it was declared a 'dangerous Book', and ordered to be burned in public $(L J, 13: 12)$. On 9 November, it was further declared a 'lying, scandalous, and seditious Book' ( $L J, 13: 14)$.

21 'The Test Bill', in Milton and Milton, Locke: Essay Concerning Toleration, 417. A nearly identical version of the clause had appeared in the Five Mile Act of 1665. 
Prince when taken prisoner by his cousin Edward the $4^{\text {th }}$ that pretended to the Crown, and that Bustling Earle of Warwicke, was carried in their Armyes gave what orders and Commissions they pleased, whilst all those that were Loyall to Him, as a Man adhered to his wife and son, and fought a pitcht Battle against him and retook him. ${ }^{22}$

Hidden in this passage of 'pro-Lancastrian' history was by analogy a scenario of armed struggle against Charles and his evil captors, to be fought by adherents to his bastard Protestant son, James Scott, $1^{\text {st }}$ Duke of Monmouth. Between the lines lay a set of explosive identifications:

Henry VI = 'soft and weak' Charles II

Edward IV = 'Cousin' Louis XIV

Earl of Warwick = 'Bustling' James, Duke of York

Margaret of Anjou = 'wife' Lucy Walter

Edward of Westminster, Prince of Wales = 'son' Monmouth

The Reasoner reflected that the case was one of 'directly taking up armes by Henry the $6^{\text {th }}$ his Authority against his person and against those that were Commissioned by him, and yet to this day no man hath ever blamed them, or thought but that if they had done other they had betrayed their Prince and been disloyall to him'. ${ }^{23}$ At first blush, it may seem that likening the shrewd and cynical Charles II to the incompetent and recurrently mad Henry VI might be a farfetched parallel. But this was not so, if we read into it a likely allusion to Charles's recent affliction with venereal disease, probably syphilis. ${ }^{24}$

The writer went on to offer another, this time apparently hypothetical, case of loyal insurgency. Suppose

a future King of England should be of the same Temper with Henry the $6^{\text {th }}$

22 Reasons against the Bill for the Test, in Milton and Milton, Locke: Essay Concerning Toleration, 410.

${ }^{23}$ Op. cit., 410.

${ }^{24}$ On this, consult Don Jordan and Michael Walsh, The King's Bed: Sex, Power and the Court of Charles II (London: Little, Brown, 2015), 230-33. 
and should be taken prisoner by any accident by Spaniard, Dutch or French, which should then be of overgrowing power enough to give them thoughts of vast Empire, and in prosecution of that, should both with the Person and Commission of the King invade England for a Conquest, were it not suitable with our Loyalties to joine with the son of that Prince for the defence of his Fathers Crown and Dignity even against the Person and Commission of the King[?] ${ }^{25}$

This scenario, while preserving the equation of Charles with Henry VI and raising the spectre of a take-over of the English government by the ambitious Louis XIV, justified support for a revolution against such a danger, which should rally behind the 'son' of the captive king.

The extant copies of the Reasons, of which there are six, have only minor variations in their texts. ${ }^{26}$ And their reproduction does not much vary in the Letter, either in surviving manuscript copies or its first printed editions of $1675 .{ }^{27}$ But the Letter contained two other passages with concealed allegory. They were spliced in between those we have just examined.

As the Person of Quality further instanced, there was,

[t]he great Case of Charles 6. of France, who being of a weak and crazie Brain, yet govern'd by himself, or rather by his Wife, a Woman of passionate, and heady humour, that hated her Son the Dolphin, a vigorous and brave Prince, and passionately loved her Daughter; so that she easily (being pressed by the Victory of Hen. 5 of England) comply'd to settle the Crown of France upon Him, to marry her Daughter to Him, and own his Right, contrary to the Salique Law. This was directly opposed with Armes

25 Reasons against the Bill for the Test, in Milton and Milton, Locke: Essay Concerning Toleration, 410-11.

${ }^{26}$ There is one possible exception. Two of the six surviving copies, both of which are from the same sub-archetype, leave out any reference to the Earl of Warwick. On this, see Milton and Milton, Locke: Essay Concerning Toleration, 410.

${ }^{27}$ On these variants, see Milton and Milton, Locke: Essay Concerning Toleration, 358-59. 
and Force by the Dolphin, and all good French Men, even in his Father's life time. ${ }^{28}$

In this piece of 'anti-Orleanist' history, it was Henry $\mathrm{V}$ who could now be identified with a conquering Louis XIV. Under the guise of the mad Charles VI and his wife Isabeau of Bavaria, Charles and his Catholic wife, Catherine of Braganza, were tarred. Queen Catherine's 'Daughter' might bring to mind Mary of Modena, who was maligned by Protestant detractors at Court as the 'Pope's daughter'. ${ }^{29}$ The dauphin, a 'vigorous and brave Prince' who fought his way to power, after having been wrongly declared illegitimate, offered an idealized avatar of Monmouth as the presumptive heir of the nation's common father in Charles.

The Person of Quality went on to supply yet one more instance of principled revolt, against 'King James of blessed Memory, who when he was a Child was seized, and taken Prisoner by those, who were justly thought no friends to His Crown or Safety'. ${ }^{30}$ This passage could be read as referring either to the abduction or rescue of James VI in the Raid of Ruthven of 1582, when Presbyterian conspirators snatched him from his proCatholic favourites in power-the French Esmé Stewart, $1^{\text {st }}$ Duke of Lennox, and James Stewart, Earl of Arran (my italics). And there may have been a prompt, through play with names, to reflect on the surprising turns of history: In 1651, Prince Charles had ennobled the Covenanter Thomas Ruthven, a clansman of the head conspirator of the Raid, for his loyalism. More recently, in August 1675, with wholly different priorities in view, Charles conferred a dukedom on Charles Lennox, his bastard son by his

${ }^{28}$ Letter from a Person of Quality, in Milton and Milton, Locke: Essay Concerning Toleration, 358.

29 There may have been some allusive word-play here. Isabeau's daughter was Catherine of Valois. Queen Catherine of Braganza was so close with Mary of Modena that, in January 1674, Mary named her new-born daughter Catherine.

${ }^{30}$ Letter from a Person of Quality, in Milton and Milton, Locke: Essay Concerning Toleration, 358. 
French mistress, Louise de Kérouaille, Duchess of Portsmouth. ${ }^{31}$

The topical themes of these sly passages in the Reasons and Letter would later be repeated in a spate of print propaganda flowing out of the Shaftesbury circle from 1679 to 1681. Published during the years of the succession crisis, a number of these works are now attributed to the incendiary Scotsman Robert Ferguson, later dubbed 'the Plotter'. ${ }^{32}$ In An Appeal from the Country to the City of 1679, 'Junius Brutus' prayed that, 'if we ever should be reduced to that extremity, either to submit to the French, or to our own Popish Successor ... God deliver us from both'. In A Letter to a Person of Honour, concerning the Black Box of 1680, it was stated: 'The D. of M. before he was taken from his Mother in Holland, and carried to Paris, went for, and was acknowledged as Prince of Wales. And consequently to undermine this Title, if in the issue he should prove so, is not less than Treason'. In A Letter to a Person of Honour, concerning the Kings disavowing the having been married to the D. of M's. Mother, also published in 1680, James was denounced for his sinister 'power over the King'; for wheedling a ruler who might be described as a 'lustfull, weak, or inconsistent Prince'; and for being a 'confederate' of Louis XIV and a French 'Pensioner', who was guilty of the 'aiding and succoring of France with English Forces till that aspiring Prince was ascended to a power and greatness not to be in any probability withstood or controlled'. At the close of this tract, the Duke of Monmouth was

${ }^{31}$ Since Lennox was so elevated on 9 August, the allusion helpfully establishes an earliest possible date for the completion of the Letter. On the problem of fixing its composition and completion dates, see Milton and Milton, Locke: Essay Concerning Toleration, 92-94.

${ }^{32}$ Scholarly accounts of Robert Ferguson's life and works include: 'Ferguson the Plotter', Blackwood's Magazine 71 (1852): 703-19; Ferguson, Robert Ferguson, the Plotter; Melinda S. Zook, ODNB, sv; Richard Greaves and Robert Zaller, Biographical Dictionary of British Radicals in the Seventeenth Century (3 vols., Sussex, 1982), sv (I); Ashcraft, Revolutionary Politics, 52-63, 359-70, 374-75, 390-94, 462-63, 482-84; Melinda S. Zook, Radical Whigs and Conspiratorial Politics in Late Stuart England (University Park, PA, 1999), ch. 4; and her 'Turncoats and Double Agents in Restoration and Revolutionary England: The Case of Robert Ferguson, the Plotter', Eighteenth-Century Studies 42 (2009): 363-78. 
proclaimed 'the Son of the Kingdom, as well as the Son of King Charles' ${ }^{33}$

\section{$\S 4$}

Discovery of the secret allegory in the Reasons and Letter may now force a chronological revision to the earliest calls by Shaftesbury, or those associated with him, for militant resistance to the Stuarts. But should it also prompt extending back in time Ashcraft's vision of the earl as the leader of a revolutionary movement, with Locke as its intellectual adjutant? The question invites the challenge, in the interests of a fuller picture, of comparing and contrasting the passages in question in the Reasons and Letter with the revolutionary activities of Shaftesbury and his comrades in the early 1680 s. We can explore these relations both at the level of gritty combat operations and committed political theory. I shall first say a few words about the history of political theories of armed resistance in Restoration England, during the 1670 s in particular. It turns out that a significant part of that past can be recovered by considering the implicit rhetorical reasoning of the call to arms in the Reasons and Letter.

Ashcraft insisted that Locke's Two Treatises lived, and moved, and had their being in Shaftesbury's revolutionary Whig movement. The Second Treatise supposedly intervened to justify armed insurgency, after multiple efforts to achieve its goals by legislative means from 1679 to 1681 - most famously through passage of an Act to exclude James II from the successionproved unsuccessful. Not for a moment did Ashcraft think that Shaftesbury may have reacted similarly, and to like worries that

33 [Ferguson], An Appeal from the Country to the City (1679), (also attributed to Charles Blount), 6-7; [Ferguson], A Letter to a Person of Honour, concerning the Black Box (1680), 6; [Ferguson], A Letter to a Person of Honour, concerning the Kings disavowing the having been married to the D. of M's Mother (1680), (original title-page had 'D. of M's. Mother'), 15 (lustfull), 16 (power), 17 (pensioner), 18-19 (promoted), 26 (son). 
failed to secure legislative remedy, in $1675 .{ }^{34}$ Into his crisis narrative Jonathan Scott subsequently sought to include, and to put front and centre, Algernon Sidney's Discourses concerning Government, composed in the early 1680s. Scott additionally worked to redefine the story as one which took in a grand return of the republican idealism that had burgeoned in England in the 1650s. In effect, he suggested that there was a gaping chronological void in attitudes and promulgations of monarchical resistance during the $1660 \mathrm{~s}$ and $70 \mathrm{~s} .{ }^{35} \mathrm{~A}$ few years later, John Marshall found Ashcraft's narrative of the genesis of Locke's great work so convincing that he felt confident enough to argue that the Second Treatise, with its sophisticated apology for armed resistance, must have been written shortly after the Oxford Parliament of 1681 , when Charles forcibly aborted a potentially successful third Exclusion Bill, through the tactic of dissolution. This contention was circular, however. As Marshall would have it, Locke must have produced the work post-Oxford, because if he did not, he could not then have collaborated with Shaftesbury in the militant plans which the dissolution occasioned. ${ }^{36}$ Such incautious speculation would tend, among other things, to discourage looking into the possibility of an earlier timing for the embrace of violent conspiratorial politics by Shaftesbury and his associates.

Yet finding agitation for armed revolt in the Reasons and Letter might now prompt more serious consideration of the state of play of resistance theory in Restoration England, especially in

${ }^{34}$ Of course, a significant difference was that, in 1675, Shaftesbury was not, as in the late summer of 1682, facing trial in which those who were to stand in judgment were City Tories, newly installed after a Whig purge.

35 See Jonathan Scott, Algernon Sidney and the English Republic, 1623-1677 (Cambridge, 1988); Algernon Sidney and the Restoration Crisis, 1677-83 (Cambridge, 1991); and England's Troubles: Seventeenth Century English Political Instability in European Context (Cambridge, 2000).

36 See John Marshall, John Locke: Resistance, Religion, and Responsibility (Cambridge, 1994), ch. 6. On problems with attempting to date the Second Treatise, see J. R. Milton's 'Dating Locke's Second Treatise', in Locke's Moral, Political and Legal Philosophy, ed. J. R. Milton (Aldershot, 1999 [1995]), 111-45. 
the decade or so before the outbreak of the Popish Plot of 1678. For this period, Scott did little to integrate the anti-government invectives of the MP Andrew Marvell into his account. This former Cromwellian's two-part Rehearsal Transpros'd, published separately in 1672 and 1673, repeatedly expressed anxieties about ungodly English rule, and did so while obsessing over the propensity of kings to patronize tyrannical ecclesiastics. When this tendency was conjoined to governing by brutal means, warned Marvell, subjects will 'ferment and tumultuate at last for their own preservation', by 'a natural force operating to expel and reject whatsoever is contrary to their subsistence'. ${ }^{37}$ Marvell had been drawn out by the fierce polemic against Protestant nonconformity on display in a rash of works by the Reverend Samuel Parker, beginning with his Discourse of Ecclesiastical Politie of 1669. ${ }^{38}$

Another thinker who delivered a counterblast to Parker was the Presbyterian minister John Humfrey. In his The Authority of the Magistrate about Religion of 1672, he pitched an absolutist counter-ideal of constitutional government, in which political

37 Andrew Marvell, The Rehearsal Transpros'd: The Second Part (1670), in The Prose Works of Andrew Marvell, vol. 1, ed. Martin Dzelzainis and Annabel Patterson (New Haven, CT, 2003), 332. Dzelzainis and Patterson have found that the passage in which this quotation appeared was borrowed by the ejected Protestant minister William Disney in his Exclusion pamphlet Nil dictum quod non dictum prius (1681). Disney was later executed for publishing the Declaration justifying Monmouth's rebellion of 1685. See their n. 573 (332). Gordon Schochet has described this moment in the work as a 'Harrington-like and possibly republican constitutionalist insistence on the importance of reforming government from time to time'; see his 'Samuel Parker, Religious Diversity, and the Ideology of Persecution', in The Margins of Orthodoxy: Heterodox Writing and Cultural Response, 1660-1750 (Cambridge, 1995), 137.

${ }^{38}$ Marvell, in both instalments of the work, conveyed a jaundiced view of kingship in practice, by portraying it as an institution so often compromised by evil rulers, like Nero and Caligula, and bad ecclesiastical counsellors. On Marvell's tactic of praising an idealized King Charles by contrasting him with Parker, consult D. I. B. Smith in 'The Rehearsal Transpros'd' and 'The Rehearsal Transpros'd: The Second Part', ed. Smith (Oxford, 1971), xi-xx (intro.). Gordon Schochet has given Parker's polemics at the turn of the 1670s much attention in his profile of the man, in 'Between Lambeth and Leviathan: Samuel Parker on the Church of England and Political Order', in Political Discourse in Early Modern Britain, ed. Nicholas Phillipson and Quentin Skinner (Cambridge, 1993), ch. 9. 
power ultimately lay 'in the mutual agreement of the people themselves in choosing their Governour and kind of Government, as they judge best for their general advantage'. Humfrey went on to remark that 'this, supposing it agreed at first to be absolute, secures it for ever being set up, and answers the end of the institution'. ${ }^{39}$ Here we see sketched the notion of eminent community power in a national state. Familiar to all students of Locke's Two Treatises, it formed the lynchpin of his justification for armed resistance in cases of governmental dissolution. ${ }^{40}$

The theoretical framework of the appeal to revolt in the Reasons and Letter made no recourse to the language of rights to depose tyrannical rulers or majestic community self-governance. More relevant to it were ideas of the sanctity of the king's two bodies, ${ }^{41}$ the duty of good royal caretaking, and the right of strict lineal monarchical succession. While in context it very provocatively urged adherence to the Duke of Monmouth, readers of the passages in question were being encouraged to take up arms against the foul play perpetrated on an incapacitated king and his royal office by evil counsellors and consorts. Mentally unfit kings and malignant royal associates figured in each of the historical illustrations in which the topical allegory insinuated itself. As we know, the Reasoner and the Gentleman of Quality

39 John Humfrey, The Authority of the Magistrate about Religion (1672), 75. Humfrey in this work defined the ends of government as consisting of the glory of the magistrate and of God's designs, as well as the common good, at a time when Charles had issued his Declaration of Indulgence (March 1672), when Parliament was not in session and would not convene again until early in 1673. For context, see Gary Stuart de Krey: 'The First Restoration Crisis: Conscience and Coercion in London, 1667-73', Albion 25 (1993): 565-80; 'Rethinking the Restoration: Dissenting Cases for Conscience, 1667-1672', Historical Journal 38 (1995): 53-83, esp. 69-74; London and the Restoration, 1659-1683 (Cambridge, 2005), 100-134.

${ }^{40}$ On this communitarian theory, as elaborated by George Lawson in his Politica Sacra et Civilis, consult Julian H. Franklin, John Locke and the Theory of Sovereignty: Mixed Monarchy and the Right of Resistance in the Political Thought of the English Revolution (Cambridge, 1978); and Conal Condren, George Lawson's "Politica" and the English Revolution (Cambridge, 1990).

41 The standard work on the subject is Ernst H. Kantorowicz, The King's Two Bodies: A Study in Mediaeval Political Theology (Princeton, NJ, 1957). 
distinguished between a treasonous and a loyal use of the dualistic monarchical theory which justified armed conflict in the name of royal authority without the king's actual consent. ${ }^{42}$ There was its lamentable uptake in 1642, when that consent was dismissed as the antics of a king seduced by evil counsellors, any recurrence of which the proposed Test Bill of 1675 sought to prevent. And there was its loyal application, when patriots took up arms to wrest executive power from evil usurpers, who had seized it, and the persons of frail kings, for destructive ends. As we have seen, the topical allegory dramatized the betrayal of England, along with an infirm Charles, by popish and French captors.

To be sure, this nightmarish projection was designed to play on fears of a Catholic royal succession and pro-French Catholic influences at court. But it could have been building on, while exploiting, Protestant non-conformist fears of Anglican persecution. Of particular interest here must be certain disturbing portrayals of a coercive Church monolith by contemporary Independent controversialists, such as John Owen and Charles Wolesley. Since 1667, they had been contributing to what Gary Stuart de Krey has characterized as a flowering of intellectual advocacy for liberty of conscience out of the non-conformist press. ${ }^{43}$ For instance, Owen, in his Truth and Innocence Vindicated of 1669, accused Parker of having connived at an 'Impious and futilous' Anglican scheme to rival that of the

42 The Tory pamphleteer Dr. John Northleigh, in his The Triumph of our Monarchy, over the Plots and Princeiples of our Rebels and Republicans of 1685, blasted this theory as one that turns on a 'damnable Distinction of parting His Majesties Person from his political Capacity, that is, making Allegiance no longer Law, than their King could maintain his Authority with Arms' (266). Northleigh further claimed that the doctrine came 'Charactered in Royal Blood' in anti-Royalist propaganda during the Civil Wars': 'they never left severing our late Soveraigns's Person from his Crown, till at last his Head too from his Shoulders' (268).

${ }^{43}$ The relevant work by de Krey is given in n. 37 above. An introduction to the subject is provided in Richard L. Greaves, Enemies under his Feet: Radical and Nonconformists in Britain, 1664-1667 (Stanford, CA, 1990), 142-66, 179-84; and Jon Parkin, Science, Religion, and Politics in Restoration England: Richard Cumberland's "De Legibus Naturae” (London, 1999), ch. 1. 
Pope's 'Canonists and Courtiers'. Its interest in 'Penalties of Hanging and Damnation' for those not bound in conscience by the pretended religious powers of a magistrate would torture all 'rational creatures guiding and determining themselves according to their own reason of things and understandings', he charged. ${ }^{44}$ In 1672, Robert Ferguson, in his Sober Enquiry into the Nature, Measure and Principle of Moral Virtue, dedicated to Wolesey, set this supposed plan in contrast to a divine order of intense religious exercise, in which 'the manacles by which we are held and enslaved, are nothing but our Practical judgement and choyce'. He felt that those who shirked its intellectual challenges by pleading 'Weakness and Impotency' were self-deceivers, with the exception only of 'meer ideots, children, and men totally deprived of the use and benefit of Reason'. ${ }^{45}$

One way or another, an apology for armed conflict against a king's person as opposed to his office had long been thought by staunch royalists to accompany bloody revolutionary 'ground games'. Hence its condemnation as a 'Traiterous Position' in the

44 John Owen, Truth and Innocence Vindicated: In a Survey of a Discourse concerning Ecclesiastical Polity (London, 1699), 115 (impious, penalties), 116 (canonists), 119 (rational). Both Parker and Locke were students at Christ Church Oxford during Owen's tenure as dean of the college. For a discussion of Owen's Truth and Innocence as a riposte to Parker, and of the possible influence of Owen on Locke, consult Ashcraft, Revolutionary Politics, ch. 2, here and there. On the different tolerationist views of Owen and Locke, consult Manfred Svensson, 'John Owen and John Locke: Confessionalism, Doctrinal Minimalism, and Toleration', Journal of European Ideas 40 (2016): 1-15.

45 Robert Ferguson, A Sober Enquiry into the Nature, Measure and Principle of Moral Virtue (1672), pp. 112 (ideots), 279 (manacles, weakness). Ashcraft has described this work as a plea for reasoned inquiry and its protocols in religious debate; see his Revolutionary Politics, 54-67, here and there. But this is somewhat misleading, in that the work is a defence and exposition of his understanding of the doctrine of salvation by grace and faith. Ferguson spoke of the soul's enhanced hermeneutical powers of Scriptural reading as conferred by 'Divine Unction' (295) and of its regeneration thereby into a 'New Protoplasm' (307). He declared the Bible to be 'accompanied with so demonstrative evidences of its being divinely inspired, that who ever denies God to be the Original Author of it, must first renounce his Reason' (292). For an overview of the jostle of published soteriological views on display in contemporary English religious polemic, see Christopher Haigh, "Theological Wars": "Socinians" v. "Antinomians" in Restoration England', Journal of Ecclesiastical History 67 (2016): 325-50. 
failed Test Bill of 1675, as well as in the Five Mile Act a decade earlier. Since, in the highly seditious passages of the Reasons and Letter, the theory indeed came parcelled up with agitation for anti-government revolt, we may well ask what connection, if any, this had to further concerted revolutionary action led by Shaftesbury. Given this propaganda, one might suppose that, minimally, there had been talk about the possibility of a real insurgency.

But in fact no evidence of such has come to light, let alone anything suggesting more developed revolutionary plotting. A search for clues, looking into which of Shaftesbury's confederates of 1681 who were arrested and charged for treason had a history of associating with him which went back as far as the publication of the Reasons might seem worthwhile. But even such a sensible approach is not likely to hold much promise in the end, not least because of the paucity of the biographical evidence. We may never know how static or fluid 'the Shaftesbury circle' was over the course of these years.

Notably, we lack surviving records that would illuminate the nature and extent of Shaftesbury's involvement with the Duke of Monmouth in 1675. Here is what we know: Back in 1673, Shaftesbury had become Monmouth's chosen deputy chief justice of royal forests in southern England. ${ }^{46}$ But relations may have cooled when the earl fell from power later that year. In any case, Monmouth sat in the Lords during the controversy over the failed Test Bill in 1675. An undated voting list has 'Monmuth' down as a proponent of the measure. However, it is unclear whether this meant he was a likely or an actual supporter of it, at the time the document was drafted. His attendance dropped off in May, possibly because he was attending to matters relating to his overseas regiment, the 'Royal English'. Stationed in France in 1672, the regiment had joined the Louis XIV's forces during the

\footnotetext{
${ }^{46}$ Monmouth, who was himself the chief justice, had named Shaftesbury to the post. This detail suggesting friendly relations between the two in 1673 has emerged in the newest biography of Monmouth: Anna Keay, The Last Royal Rebel: The Life and Death of James, Duke of Monmouth (London, 2016), 140.
} 
third Anglo-Dutch war, which had ended in $1674 .{ }^{47}$ Its latest recruits were ordered home, and further recruits prohibited, by a royal proclamation published on 19 May. ${ }^{48}$ During the summer, Monmouth and his Scottish duchess hosted a recreational outing for James and his family. Two days earlier, his pregnant mistress, who was a maid of honour for Mary of Modena, had disappeared from the household. ${ }^{49}$ Monmouth attended the next parliamentary session in late October; meanwhile, he had given his proxy to James. ${ }^{50}$ In early November, he was a member of the Lords committee appointed to discover the author, printer, and publisher of the Letter. ${ }^{51}$ Shaftesbury later marked Monmouth as triply 'vile' on his list of lay Peers and MPs, which he annotated

${ }^{47}$ A detailed account of Monmouth's Royal English is given in John Childs, 'The British Brigade in France, 1672-1678, History 69 (1984): 384-97.

48 The Commons had addressed Charles on 21 April, asking for a recall of the troops, in accord with an initiative put forward in the House two days earlier. However, Charles did not give an answer until 8 May, at which time he promised to enforce a ban on new recruits. A few days later, the Commons then resolved to urge their recall in another address, which met with Charles' publication of a proclamation on 19 May, which ordered the return of troops who had gone into the French service before terms of peace had been concluded with the United Provinces in 1674, and again prohibited new recruits. See $C J, 9: 319,321,331,332,333,334,335,337$. And some lively debates over the issue were recorded in Anchitell Grey, Debates of the House of Commons (10 vols., London, 1763), III, 3, 9, 97, 103-5, 115-39.

${ }^{49}$ On this, see The Bulstrode Papers, ed. Alfred Morrison, in The Collection of Autograph Letters and Historical Documents, vol. 1 (1897), 311.

${ }^{50}$ Keay suggests that Monmouth became permanently alienated in his affections from James in the spring of 1678. For in April, James had seen to it that his father's signed patent, for making Monmouth captain-general of the armed forces, was revised to reference his bastard status of 'natural son'; the original address simply spoke of 'our most entirely beloved son James Duke of Monmouth'. She also covers in detail Monmouth's decisive rejection of a pro-French foreign policy a year later, when by Charles's orders, he pulled his regiment out of Louis XIV's army, and was put in command of new forces in Ostend who would now be fighting for the Dutch. But she believes he had been disturbed about their thankless treatment by the French government some years earlier. See her Last Royal Rebel, ch. 10. For more details on Monmouth's life in the 1670s, in particular his parliamentary activity in the Lords, see HoP: Lords, 1660-1715, 4:375-78, under James Scott (by Ruth Paley).

${ }^{51}$ See $L J, 13: 12$. 
during his year-long stay in the Tower from February 1677; although, needless to say, this is most unlikely to have been his view just a couple of years later, when Monmouth's talks with him over opposition machinations are thought to have first begun. ${ }^{52}$

While this thin historical record does not permit grounded conclusions about the nature of relations between Shaftesbury and Monmouth in 1675, revealing evidence on the duke's relations with Locke at this time is altogether lacking. The upshot is, we just do not know whether, at some point in 1675, Monmouth was privy to the insurrectionary scheme adumbrated in the Reasons and Letter. Indeed, because that appeal to arms was itself clandestine, it is not even possible to say with confidence that Shaftesbury, among those responsible for authoring the pamphlets, had penetrated the allegory.

\section{$\$ 5$}

Consideration of the concealed parallels in the Reasons and Letter throws up another question, not hitherto entertained, about 'the Shaftesbury circle' and its operations. It has to do with our interpretive approach to its written compositions prior to the late 1670s. Does the sort of suspicious reading of documentary evidence undertaken by Ashcraft to reconstruct a revolutionary Whig movement become relevant at an earlier date? It was Ashcraft who insisted that 'efforts of individuals to disguise their intentions, conceal their political objectives, and create a language filled with ambiguity, irony, double meanings, and falsehoods, in order to protect themselves in a situation in which imminent death was likely to be the consequence of discovery or

52 The list is reproduced and commented on in K.H.D. Haley, 'Shaftesbury's Lists of the Lay Peers and Members of the Commons, 1677-8', Bulletin of the Institute of Historical Research 43 (1970): 88-105. Keay, who follows the standard view in maintaining that Shaftesbury and Monmouth got down to serious conversation about opposition strategies and tactics only after the outcome of the General Election of February 1679, remarks that '[w] hat interaction they had had over the five years since the older man had been Monmouth's deputy as chief justice of the southern royal forests is not clear; quite possibly very little' (198-99). 
miscalculation have bequeathed to posterity a record that is, at best, opaque'. 53

What about Locke and the incendiary passages of the Reason and Letter? So far, there is little to go on, as regards his possible involvement in their authorship. What information we have about his departure to France in November 1675 might now be seen in a fresh way, however. It seems that Ashcraft was misled in suggesting that a fear-stricken Locke suddenly bolted across the Channel when the Letter was condemned. Locke's advance preparations for that trip are inconsistent with this proposal. ${ }^{54}$ I would point out, though, that the timing of Locke's procurement of a bill of exchange for $£ 20$, on 2 May 1675, which he directed to a merchant at Nantes, roughly coincided with the circulation of the Reasons that month. ${ }^{55}$ Of course, this could have been mere coincidence.

Ashcraft argued the probability that Locke equivocated in later denials that he had ever authored seditious libels. ${ }^{56}$ Yet efforts to attribute to Locke's hand the parallels concealed in the Reasons and Letter must now contend with information that points in two opposite directions. It is true enough that Locke was one to cover his tracks. But there is no way of knowing whether this would have translated into deploying verbal cunning in seditious propaganda. Locke's own prose is largely devoid of historical

${ }^{53}$ Ashcraft, Revolutionary Politics, 341.

${ }^{54}$ Locke's preparations for the trip are sketched in Maurice Cranston, John Locke: A Biography (London, 1968 [1957]), 160-61.

55 This bill of exchange, which suggests that Locke may have been planning his trip to France for some time, is noted in Milton and Milton, Locke: Essay Concerning Toleration (99). That the Reasons was released in May 1675 is suggested by an endorsement in an extant copy that reads 'May 1675 Reasons against the Test at present under debate in the House of Lords'; see, for corroboration, Locke: Essay Concerning Toleration, 238. Subsequently, from June through early October, J. R. Milton believes that Locke went to stay with Shaftesbury at his Dorset residence, since Locke's expense entries in his ledger trail off during this time; on this, see his 'The Unscholastic Statesman: Locke and the Earl of Shaftesbury', in Anthony Ashley Cooper, First Earl of Shaftesbury, 1621-1683, ed. John Spurr (Farnham, 2011), 160.

${ }^{56}$ See Ashcraft, Revolutionary Politics, 120-22. 
argument or illustration, as many scholars have remarked. It is not impossible, however, given his penchant for secrecy, that he might on rare occasion have made deceptive use of this mode of writing as not readily identified with his own stylistic habits.

The allegory in the Reasons and Letter also raises the question of further verbal duplicity. How far did they echo flights of oratory by Shaftesbury in Parliament? In 1681, the poet laureate John Dryden, in his Absalom and Achitophel, famously satirized the Earl as a political dare-devil: 'A daring Pilot in extremity / Pleas'd with the Danger, when the Waves went high / He sought the Storms; but for a Calm unfit, / Would Steer too nigh the Sands, to boast his Wit. / Great Wits are sure to Madness near ally'd; / And thin Partitions do their Bounds divide'. ${ }^{57}$ But it would strain credibility to apply this diagnosis to the absurd scenario of any Peer delivering a call to arms, however much disguised, against the government in the Lords.

The text of the Reasons bore markers that suggested it was a pre-prepared script, or later transcript, of a nobleman's speech on the Bill therein. It used a first-person point of view throughout, with appeals to 'My Lords' made in its two final paragraphs. Half of the surviving copies advertised the work as 'by the Earl of Shaftesbury'. ${ }^{58}$ The text of the Letter, however, tended to give a different impression when borrowing material from the Reasons. While employing a third-person perspective, it introduced the reproduced material here and there, without attributing any of it to individual Peers. Either no attributions were given, or else they were non-specific. Repeatedly, the latter took passive impersonal

${ }^{57}$ John Dryden, Absalom and Achitophel (1681), in The Works of John Dryden, ed. H.T. Swedenburg, 20 vols. (Berkeley, CA, 1972), 2:10 (11. 159-64).

${ }^{58}$ See the descriptions of these copies (in TNA, the Surrey History Centre, and the Beinecke Library) in Milton and Milton, Locke: Essay Concerning Toleration, 239. Interestingly, four of the copies of the Reasons began the second passage with concealed meaning by stating 'The other Instance, put case a future King of England should be of the same temper with Henry the $6^{\text {th'; }}$;hereas two of the copies have 'suppose' for 'put case'. This 'put case' made it look as if a cue to a speaker were being given; on this variant, Milton and Milton, Locke: Essay Concerning Toleration, 242-43, 410. 
constructions - 'it was said', 'it was farther offered', and the like. On two occasions, a general assignment was in the plural- 'the Country Lords'.

It is no wonder that the few contemporary accounts which reflect on the correlation between oratory in the Lords and its written equivalent in the Reasons, and in those passages in the Letter which borrow from the latter, assigned the supposed written versions either to Shaftesbury, acting nearly alone, or to a number of his allies in the campaign against the Bill, whose names went unspecified. ${ }^{59}$ For it is likely that their authors were influenced, one way or another, by having a copy of the Reasons or the Letter (or both) to hand, believing they were commenting reliably on the proceedings in the Lords. No contemporary account cast doubt on the very existence of a correspondence between the content of the Reasons and parliamentary speeches opposing the measure.

One interesting later account is given in Gilbert Burnet's unrevised 'History of My Own Time'. Composed sometime after 1683, it consisted of his rehearsal of the sum and substance of the debates on the Bill in the Lords. Writing from a position of strong sympathy with opponents of the Test, he assumed that the case of Henry VI had indeed been invoked by them. As he recapped the highlights of their performance:

[S]peculative opinions about $\mathrm{y}^{\mathrm{e}}$ limits of Power and obedience were not proper matters for an Oath, since cases may be put and had really been $y^{\mathrm{e}}$ case of Henry $y^{\mathrm{e}}$ sixth. these were very tender points to be much debated when $y^{\mathrm{e}}$ majority of $\mathrm{y}^{\mathrm{e}}$ House was resolved to have sent any of $\mathrm{y}^{\mathrm{e}}$ Peers to Prison $\mathrm{y}^{\mathrm{t}}$ had given just advantage against them. Shaftesbury gained more Credit in this session than he had ever done in his whole life, for he argued to admiration, and one day he spoke about an hour for $\mathrm{y}^{\mathrm{e}}$ lawfulness of resistance in some cases so wittily and yet so dexterously $y^{t}$ thô his

59 This interpretive divide can be discerned in current scholarship on the Reasons and Letter. Compare, for instance, Milton and Milton, Locke: Essay Concerning Toleration, 86-87, 89-90; and HoP: Lords, 1660-1715, 2:297, under Ashley Cooper (by Paul Seaward). 
enemies were watching when he should let any thing fall $\mathrm{y}^{\mathrm{t}}$ might be turned against him yet they could not find it. ${ }^{60}$

Burnet did not here say specifically that it was Shaftesbury who raised the case of Henry VI. In any event, he seems to have felt that to do so in order to reject the proposed oath was a risky move. His claim that it was Shaftesbury's dexterity which foiled retribution from those ready to pounce on him for uttering dangerous words cannot be verified in contemporary accounts. He may have been trying to reconcile the passages in question in the Reasons or Letter, which he construed innocently, with what he thought was too 'tender' for parliamentary oratory. ${ }^{61}$

Another account of this matter was given in a copy of the Reasons which seems to have been possessed by Lord Keeper Finch. ${ }^{62}$ His son, Daniel (later $2^{\text {nd }}$ Earl of Nottingham), wrote on it that, whereas the Reasons were '[g]iven out to be fram'd by Lord Shaftesbury and intended to have bin spoke by him in Parliament at the reading of the bill engrost', they were actually 'a collection of all the arguments that were used by the severall lords that spoke against the Test, and here putt together in one

${ }^{60}$ Gilbert Burnet, 'History of my own life', BL, Add MS 63057 B, f. 31'; and compare Burnet's History of My Own Time, ed. Osmund Airy, 2 vols. (Oxford, 18971900), 2:83-84.

${ }^{61}$ Contrariwise, Shaftesbury's biographer, John Martyn, or others who contributed to the project, perhaps decided that these could not be reconciled, especially if the coded messages in the passages in the Reasons had been detected. For there is the unexplained omission of the Reasons from the printings of Martyn's Life of Shaftesbury. In 1744, Martyn received a copy of the work. At that time, he had high praise for it, and was fully resolved to include it in his biography. On this, consult J. R. Milton, 'Benjamin Martyn, the Shaftesbury Family, and the Reputation of the First Earl of Shaftesbury', Historical Journal 51 (2008): 315-35.

62 This copy was preserved in the Finch Papers in the Leicestershire RO. Consequently, as Milton and Milton remark, '[i]t is likely that the manuscript was acquired by Heneage Finch ... [A]s Lord Keeper and one of the chief promoters of the bill he would have been very interested in the activities of its opponents' (Locke: Essay Concerning Toleration, 239). Daniel Finch's remarks in it are undated. 
entire discourse'. ${ }^{63}$ Could it be that this was largely true? Or did his father Heneage tell him so, because he could not recognize the passages in question as having featured in Shaftesbury's oratory, which he had heard first-hand?

So, to whom was the allegory pitched? Who, if anyone, sifted the concealed parallels? In fact, no certain information has come to light as to their detection by actual readers. In a briefing for 8 November 1675, the diplomat Richard Bulstrode was simply told that the Letter was brought into the Lords by a bishop, where it met with condemnation that day; and that it contained 'sharp reflections \& remarques upon several bishops and some great ministers of State'. ${ }^{64}$ The next month, Charles issued a proclamation for closing down the coffee-houses. But there is no way of knowing if this was connected to the circulation of the Letter, let alone to the possible detection of its disguised passages by government officials. It could have been a response to what was now a series of political tracts coming out of the Shaftesbury circle. From the government's standpoint, the risk of a more aggressive assault on the contents of the Letter was that this might generate more readers for the tract than it would have otherwise had. A second edition of the work may have already been produced in order to take advantage of the publicity which had come from its public burning in November. ${ }^{65}$ Another hazard was that damaging facts and rumors might spill out, such as could have followed from the revelation of its allegory.

Late next year, there appeared the closest engagement with the Letter of which we know. This came in Marchamont Nedham's stinging intervention, A Pacquet of Advices and Animadversions, Sent from London to the Men of Shaftesbury of 1676. Nedham thought that the passages in question were curious, but that was

${ }^{63}$ Leicestershire Record Office, DG7, Finch Parliamentary and Political Papers 30; quoted in Milton and Milton, Locke: An Essay Concerning Toleration, 239.

${ }^{64}$ Bulstrode Papers, ed. Morrison, 322.

${ }^{65}$ For more on this second edition, consult Milton and Milton, Locke: Essay Concerning Toleration, 195-210. 
all: 'The LETTER, tells also, what other strange Instances were Preached in the same House, and selected out of the times of some weak Princes, to shew, that sometimes it can be no Traiterous Position, to affirm, That Subjects may take Arms against persons Commissioned by the King, though the King be among them in Person'. ${ }^{6}$ For those, like Nedham here, who assumed that portions of the Reasons or the Letter accurately represented Shaftesbury's rhetoric in the Lords, the passages would read innocently enough, since to suppose otherwise required belief that Shaftesbury could indeed, however slyly, have advocated armed conspiracy right in front of the Peers, and been spared life and limb in doing so. ${ }^{67}$

Although there is little on record about how the allegory in the Reasons and Letter was received, it is not difficult to imagine contemporary readers situated in networks where they could be tipped off to decode their stealthy agitation. ${ }^{68}$ In such milieux, one erudite figure, trained in biblical hermeneutics, stands out: the politically engaged clergyman Robert Ferguson, from London's culture of Dissent. A native of Aberdeenshire who came to England at mid-century, he had worked as a Presbyterian divine until, on St Bartholomew's Day in 1662, he suffered ejection. Some time in the 1670 s, he converted to Independency. In 1685, he numbered among the conspirators who accompanied

${ }^{66}$ [Marchamont Nedham], A Pacquet of Advices and Animadversions sent from London to the Men of Shaftesbury (1676), 73. In 1682, Robert Ferguson alleged that the Earl of Danby bribed Nedham to write this work and its sequel, A Second Pacquet of 1677; see his Third Part of No Protestant Plot, 58-59. There may be something to this, since Danby was privy to draft-versions of the texts. He sent these to his friend William Scroggs (later Chief Justice) for feedback; see Scroggs's undated letter of reply, in which he offered suggestions for revision: BL Egerton MSS 28053, fo. 114.

${ }^{67}$ As for Monmouth himself, he was in attendance in the House during the debates, and was probably a supporter of the Test Bill; consult the list of proponents of the Bill which names 'Monmoth', in BL MS 28091, f. 177.

${ }^{68}$ In 1680, another tract out of the Shaftesbury circle, entitled A Speech lately made by a Noble Peer of the Realm, seems to have been thus 'secretly circulated'; on this, consult Mark Knights, Politics and Opinion in Crisis, 1678-81 (Cambridge, 1994), 171. For discussion of this work, see Haley, First Earl of Shaftesbury, 612-14. 
Monmouth from Holland, and took part in the failed uprising. ${ }^{69}$

Ferguson must be a prime suspect for participation in the production of the Reasons and Letter, and even perhaps for exclusive collaboration with Shaftesbury in their composition. ${ }^{70}$ His later tracts for Shaftesbury abound with the kind of historical examples from English, continental, and Scottish politics to be found in their disguised passages. ${ }^{71}$ For instance, in his Letter to a Person of Honour, concerning the Kings Disavowing (1680), he observed of Charles' solemn declaration that he had never married Lucy Walter: ${ }^{72}$ 'call to mind the Character fastened upon Charles the ninth of France, namely, that the surest Symptomes by which it was known when he spake falsly, was the endeavouring to confirm what he said by the most dreadful Imprecations, and execrable Oathes'. Ferguson continued:

[W] hat our own Historians leave upon the memory of his Royal Majesties own Grandfather in this point, I had rather you should learn from Wilsons History of King James, than be told by me. Besides, say others, who knowest but that the King through the like Impression of fear, under which he lifted up his Hand to the most high God at Scone when Crown'd in Scotland, may have been influenced and overaw'd to make this late Appeal

69 For more biographical information on Ferguson, including his later transformation into a most penitent Jacobite, see my n. 29 above.

${ }^{70}$ Ferguson's first known connection to Shaftesbury dates from period 1679 to 1682. Milton and Milton note the anomalous presence of biblical language, drawn from the Old Testament in particular, in the Letter, if we assume that Shaftesbury and Locke were the only collaborators in its production (Locke: Essay Concerning Toleration, 117). This language was well known to Ferguson, in his works of religious controversy. One good starting-point for investigating his candidacy as author of the critical passages in the Reasons and Letter, and as an author of both these works, would be stylometric work. On some challenges posed by the construction of a Ferguson canon, consult Zook, Radical Whigs and Conspiratorial Politics, ch. 4, n. 25.

71 A number of these were drawn from Philip de Commines's 'Memoirs', which Ferguson cited in his An Appeal from the Country to the City (1679), 11, and Letter to a Person of Honour, concerning the Kings Disavowing (1680), 4.

72 Charles's Declaration to that effect was published on 2 June. This Ferguson pamphlet was dated 10 June. 
and Protestation. ${ }^{73}$

Ferguson was professionally equipped to know how such examples could be freighted by rhetorical agility with double meaning. In early 1675 he published a treatise, The Interest of Reason in Religion; with the Import \& Use of ScriptureMetaphors, dealing with the question of figurative language in the Bible. There he challenged accusations by Samuel Parker and William Sherlock that the non-conformist Protestant clergy were guilty of fancifully intruding 'fulsom and lucious metaphors' into the plainer sense of the Scriptures. ${ }^{74}$ On the contrary, retorted Ferguson, it was necessary that 'we impose not a proper sense where the words ought to be taken in a Tropical, Figurative, Metaphorick, or Allegorick one'. ${ }^{75}$

We owe it to the work of Ashcraft that this could be taken as something of a motto in the early publications of Shaftesbury and his circle. However, in the peak years of their campaign against the threat of a Catholic succession to the throne, some five years later, such masks could be thrown off. At the outset of his Letter to a Person of Honour, concerning the Kings Disavowing, Ferguson would write, and would make good on his word: 'My Lord, As you cannot but have seen his Majesties Declaration, wherein he Renounceth the having been Married to the $D$. of $M$ 's. Mother; so I believe you will not be displeased to have an account of the sence of the Thinking-men about the Town concerning it. And this without either disguising, or concealing what is publickly discoursed, I shall, as becomes your Lordships servant, address my self to give you' ${ }^{76}$

73 [Ferguson], Letter to a Person of Honour, concerning the Kings Disavowing, 11.

${ }^{74}$ Ferguson, The Interest of Reason in Religion, with the Import \& Use of ScriptureMetaphors (1675), 278-79 (metaphors). Parker, in his Discourse of Ecclesiastical Polity of 1671, had stated that, '[H]ad we but an Act of Parliament to abridge Preachers the use of fulsom and luscious Metaphors, it might perhaps be an effectual Cure of all our present Distempers' (76).

${ }^{75}$ Ferguson, The Interest of Reason in Religion, 328.

${ }^{76}$ [Ferguson], A Letter to a Person of Honour, concerning the Kings Disavowing, 1. 
The times had changed. In the spring of 1679 , the first Exclusion Bill was debated in the Commons, and the Licensing Act lapsed in May, (not to be renewed until 1685). There followed a surge of pamphlets openly calling for supported Exclusion and other schemes for eliminating or reducing the powers of a Catholic royal successor. ${ }^{77}$ By the autumn of 1682, the forces of Tory reaction had gained the upper hand over Whig conspirators, however. In December, Shaftesbury fled to Holland accompanied by Ferguson, where a month later he died in 'his servant's arms', as it was reported. So ended a relationship with 'the Plotter', whose first fruit may have been collaborative work on the Reasons and Letter.

University College, London

77 The classic account of this period is Knights, Politics and Opinion in Crisis. 